\title{
Current state of the fishing industry in the Krasnodar region and its contribution to the country's food security
}

\author{
Alexey Abramchuk ${ }^{1, *}$, Georgy Moskul ${ }^{1}$, Natalia Pashinova $^{1}$, Ksenia Abrosimova ${ }^{1}$, and \\ Mariya Kozub ${ }^{1}$ \\ ${ }^{1}$ Kuban state University, 149 Stavropol str., Krasnodar, 350040, Russia
}

\begin{abstract}
The paper contains information about the current state of the fishing industry of the Krasnodar territory, the resource base of which is industrial fishing and aquaculture, which is represented by various categories of farms (pond, cage, basin, mariculture). Detailed data on the production of aquaculture products for various categories of farms in the Krasnodar territory are provided. The most developed areas are pasture and pond fish farming, accounting for more than $90 \%$ of the region's commercial aquaculture products. The main cultivated objects are various breeds of carp (carp) (Cyprinus carpio), white carp (Hypophthalmichthys molitrix), mottled carp (Hypophthalmichthys nobilis) and white Cupid (Ctenopharyngodon idella). The characteristic of the mariculture of the region is given. The results of industrial fishing in the Azov-Black sea basin are considered. The contribution of the fishing industry of the Krasnodar territory to the country's food security is determined.
\end{abstract}

\section{Introduction}

The Russian fisheries industry is an important sector of the national economy and plays a key role in maintaining the country's food security. Providing a total of about 3 million people in the country for individual subjects, mainly coastal ones, it is crucial in ensuring social stability. The resource base of the industry is industrial fishing and aquaculture, which is represented by various categories of farms (pond, cage, pool, mariculture, etc.). Providing the country's population with fish products, which are a source of irreplaceable components of animal origin, is a priority task, the solution of which is defined in the strategy for the development of the fisheries complex of the Russian Federation for the period up to 2030 and The doctrine of food security of the Russian Federation. Fish products, with their unique amino acid, fat and vitamin composition, play a key role in

\footnotetext{
* Corresponding author: apilab@yandex.ru
} 
ensuring a balanced diet and a healthy diet of the population. By average per capita consumption of fish and fish products in comparison with the world's leading fishing powers (China, Norway, Japan, the United States of America) The Russian Federation is in 5-th place. In all countries, aquatic biological resources and products obtained from aquaculture facilities are given a special place in the formation of national food security. The development of the domestic fisheries sector is facilitated by the raw material base of fishing, which is estimated at 5.2 million tons in total for 2019 [1-5].

Commercial aquaculture in Russia currently occupies a relatively low place in the production and economic structure of the industry. It reached its peak in the late $80 \mathrm{~s}$ of the XX century, when the production of commercial aquaculture in the Soviet Union amounted to more than 400 thousand tons. Today, the pace of its development and production volumes are significantly inferior to the leading countries in this direction (China, Norway, Vietnam, etc.) [6-8]. The produced aquaculture products are almost completely focused on meeting the needs of the domestic market, however, it is worth noting the gradual increase in production volumes with the expansion of the species and breed diversity of cultivated hydrobionts.

The legal basis for fishing, commercial aquaculture and conservation of aquatic biological resources is Federal law № 349-FZ "On amendments to the Federal law "On fishing and conservation of aquatic biological resources" and certain legislative acts of the Russian Federation in terms of improving the distribution of quotas for production (catch) of aquatic biological resources" and Federal law № 148-FZ "On aquaculture (fish farming) and on amendments to certain legislative acts of the Russian Federation".

According to the Ministry of agriculture of Russia at the end of 2019, the production of aquaculture products by fish farms of the Russian Federation approached 250 thousand tons, of which more than $30 \%$ (78.7 thousand tons) were grown by fish farms operating in the Azov-Black sea fisheries basin [9]. In the South of Russia, there are about 800 enterprises of various types, including farms, state-owned and plants for the reproduction of various types of fish. The expansion of pond areas, the increase in the number of farms and the use of intensive aquaculture methods allow increasing production volumes.

\section{Discussion}

Krasnodar territory has a significant Fund of fishing reservoirs that are used as sites for industrial fishing and aquaculture in various categories of farms (the waters of the Black and Azov seas, the Azov-Kuban estuaries, reservoirs, riverbed reservoirs of steppe rivers, etc.) (Fig. 1). The total volume of aquaculture production in the Krasnodar territory in 2019 amounted to more than 21.5 thousand tons.

The most developed areas are pasture and pond fish farming, accounting for more than $90 \%$ of the region's commercial aquaculture products. 


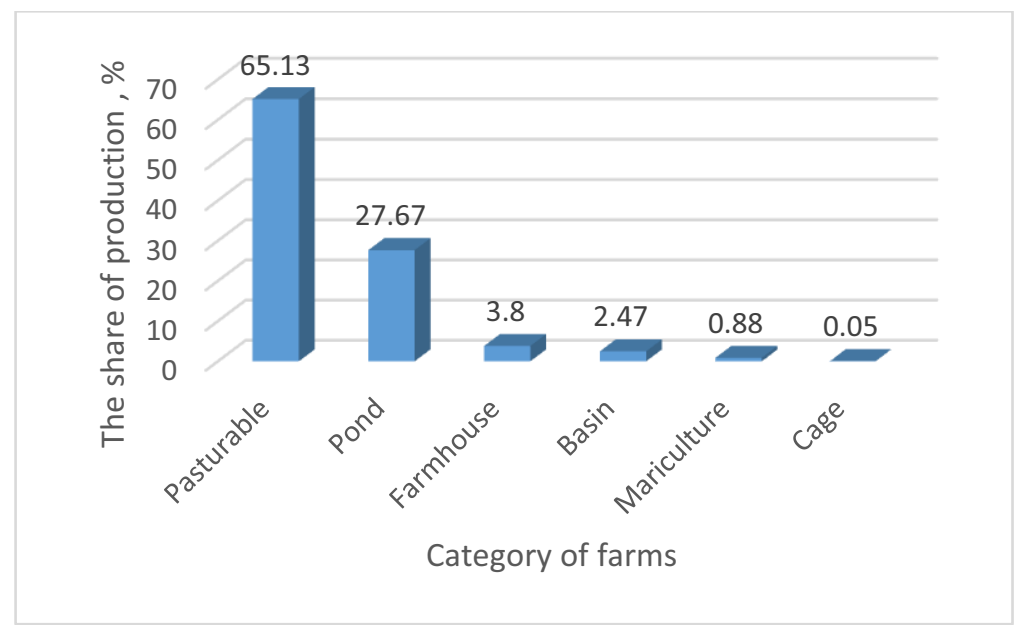

Fig. 1. production of commercial fish and other industrial fish farming facilities in the Krasnodar territory.

Pasture cultivation of aquaculture objects is carried out on an extensive approach. Fish farms of this category operate mainly on riverbed reservoirs of lowland rivers, reservoirs and estuaries [10].

In the Krasnodar territory there are 3 reservoirs with a total area of 47.9 thousand ha, including Krasnodar area of 40 thousand hectares - pond two regions (Krasnodar Krai and Adygeya Republic); Kryukovskaya area of 4 hectares and Varnavinsky - 3,9 thousand hectares. The Area of the Azov-Kuban estuaries is 126 thousand hectares. Of these, 31 thousand hectares are occupied by spawning and breeding farms, 49 thousand hectares are occupied by fishing areas, the rest of the estuaries can be used for pasture fish farming ( 30 thousand hectares) and Amateur fishing (16 thousand hectares). The rivers of the AzovKuban plain Yeya, Chelbas, Beysug, Kirpili, Ponura, Albashi, Yaseni and their tributaries are regulated and represent a cascade of reservoirs (ponds-reservoirs) with an area of 5-10 to $300-500$ hectares or more. According to Kubangiprovodkhoz, there are about 1300 reservoirs on the rivers of the Azov-Kuban plain, with a total area of about 50 thousand hectares $[11,12]$.

The key approach to intensification in these farms is directed reconstruction of the ichthyofauna based on indicators of the forage potential of the water body, while the scientifically based selection of polyculture objects allows rational use of the natural forage base of the reservoir. Two allochthonous species of the genus Hypophthalmichthys occupy a special place in the reconstructed ichthyocenoses, feeding on planktonic organisms (zoo and phytoplankton) they are practically devoid of trophic competition [13, 14].

The main cultivated objects are various breeds of carp (Cyprinus carpio), white carp (Hypophthalmichthys molitrix), mottled carp (Hypophthalmichthys nobilis) and white Cupid (Ctenopharyngodon idella) (Fig. 2). 


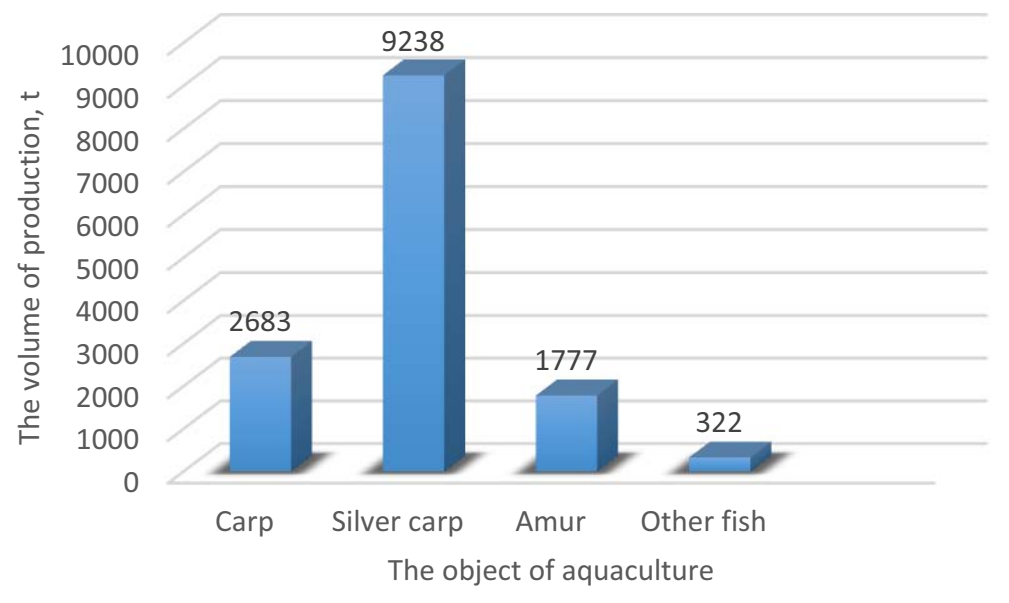

Fig. 2. Production of commercial fish in the Krasnodar territory by means of pasture aquaculture in 2019

The share of white and variegated silver carp accounts for the main part of the production (65.9\%), the production of carp and Amur carp was 19.1\% and 12.7\%, respectively. The volume of production of other fish species (pike (Esox lucius), walleye (Sander lucioperca), tench (Tinca tinca), perch (Perca fluviatilis), crucian carp (Carassius gibelio), bream (Abramis brama), roach (Rutilus rutilus), etc.) by pasture aquaculture farms was about $2.3 \%$.

The second place is taken by pond fish farming (Fig. 3). The species composition of the cultivated aquaculture objects in the pond farms of the region corresponds to that which is cultivated according to the pasture principle.

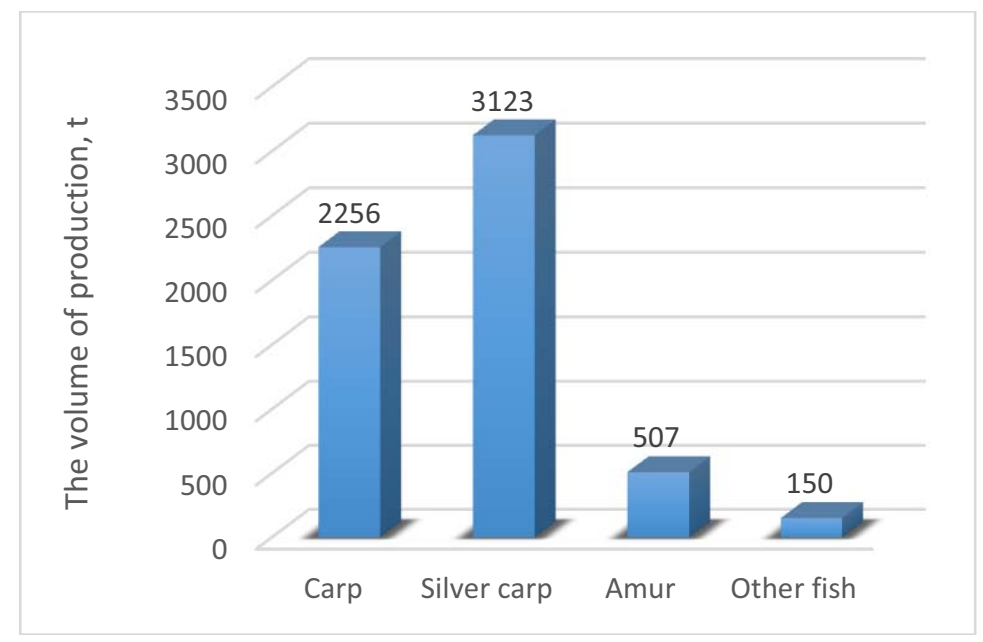

Fig. 3. production of commercial fish in the Krasnodar territory by means of pond aquaculture in 2019.

The total production of commercial fish products of pond aquaculture in the Krasnodar territory in 2019 amounted to more than 6 thousand tons. The Main share $(51.7 \%)$ is accounted for by the production of white carp (Hypophthalmichthys molitrix) and pied carp 
(Hypophthalmichthys nobilis). The share of carp (carp) (Cyprinus carpio) - the most common and valuable object, accounts for about a third of the total volume of fish products produced (37.4\%). During the analyzed period, the region's pond farms produced about 0.5 thousand tons. White cupid (Ctenopharyngodon idella), which is $8.4 \%$ of the total volume. In addition to typical objects of warm - water polyculture, pond aquaculture in the region produced about 2 tons of a typical cold-water object-rainbow trout (Oncorhynchus mykiss).

The creation of peasant farms in the Krasnodar territory significantly contributes to improving the standard of living of the rural population of the region. The creation of conditions for the sustainable development of farms of this type and the development of a market network (fairs), where products are presented by the direct producer, contribute to the increase in the production of agricultural products, including fish. The nature of the water body and the selected technology of cultivation of hydrobionts determine the type of fish farming (pond and cage farms, pasture farms, etc.). The total volume of farm fish production in 2019 was more than 800 tons. In addition to typical freshwater aquaculture species - carp (Cyprinus carpio), white (Hypophthalmichthys molitrix) and mottled (Hypophthalmichthys nobilis) carp, amur (Ctenopharyngodon idella), sturgeon species are grown in the region, mainly sterlet (Acipenser ruthenus) and russian sturgeon (Acipenser gueldenstaedtii).

An important role in the production of fish products is occupied by cage and basin farms with a production volume of 540 tons in 2019 (Fig. 4). The main objects of which are sturgeon and salmon fish species.

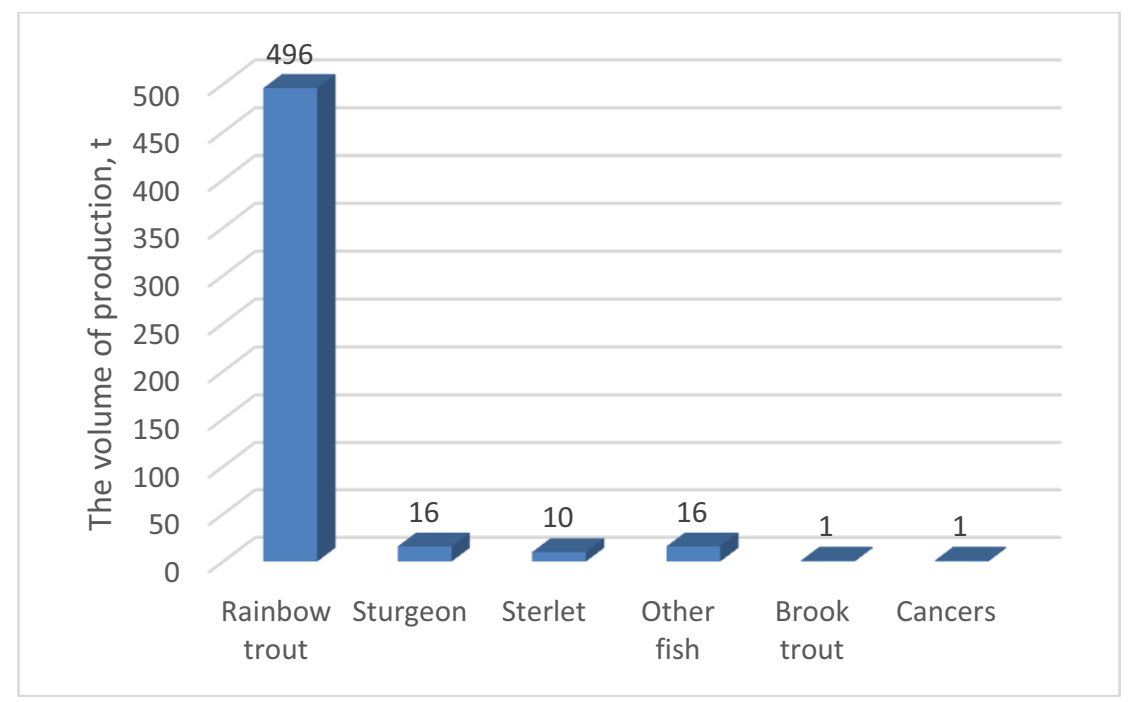

Fig. 4. Production of commercial fish in cage and basin farms of the Krasnodar territory in 2019.

Rainbow trout (Oncorhynchus mykiss) accounts for the main share of commercial fish production in the Krasnodar territory's cage and basin farms (92\%). Its characteristic fishbreeding and biological indicators and meat, which is rich in unsaturated fatty acids, trace elements and vitamins, make rainbow trout the most promising and popular object of aquaculture in the region. This is also facilitated by the intensive development of the tourist infrastructure of the Krasnodar territory and, above all, the black sea coast, which ensures the growth of the consumer market. A significant part of the manufactured products is sold in fresh (chilled) form. In addition to rainbow trout (Oncorhynchus mykiss), sturgeon (russian sturgeon (Acipenser gueldenstaedtii), sterlet (Acipenser ruthenus), Siberian 
sturgeon (Acipenser baerii), Beluga (Huso huso) and their hybrids). Sturgeon are kept at fish farms in the region not only for the purpose of obtaining meat and caviar products, but also for the purpose of reproducing and maintaining the natural biodiversity of the ichthyofauna [15-17]. There is a fairly high demand in the region for freshwater crayfish, but their share in commercial aquaculture in the Krasnodar territory is very small, in 2019, about one ton was produced.

To date, the results of shellfish cultivation in Russia are very modest and mariculture is only developing, in contrast to other countries of the black sea basin - Turkey and Bulgaria. The waters of the Black and Azov seas in the southern regions of Russia are now considered as the most promising areas for the development of domestic mariculture. The nature of the consumer market of the Krasnodar region and the increased demand for seafood determine the dynamic development of this part of the industry. The most common objects of mariculture around the world and in the Krasnodar territory in particular, are primarily bivalve mollusks - mussels and oysters. The total volume of mariculture production in 2019 was 190 tons, with mussels accounting for about $80 \%$ (Fig. 5).

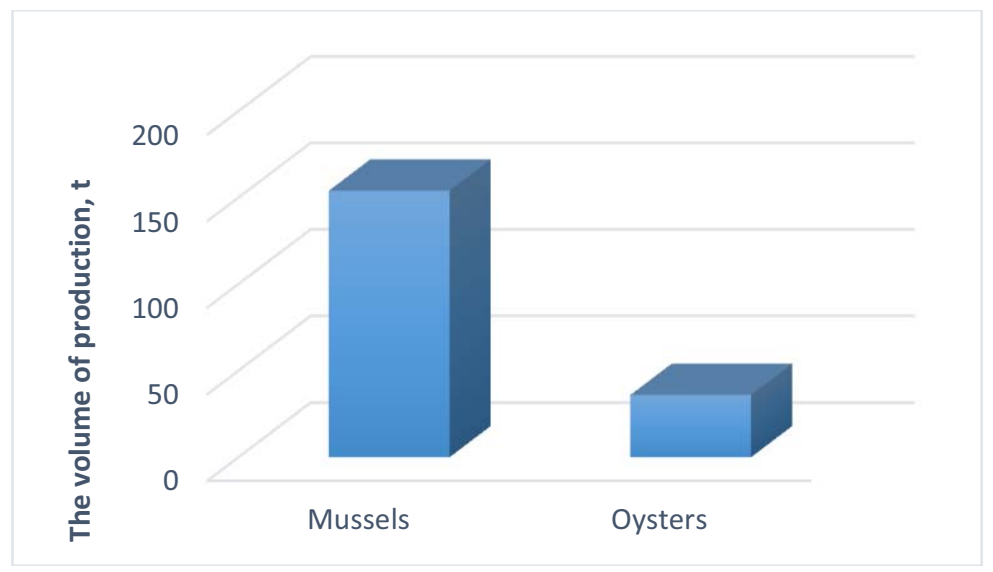

Fig. 5. Shellfish production in the Krasnodar region in 2019

Among the most common species of these invertebrates that are used in domestic mariculture are the common or edible mussel (Mytilus edulis) and the Pacific oyster (Crassostrea gigas). At the same time, the native species for this area - the black sea oyster (Ostrea edulis) during the twentieth century has undergone significant pressure from fishing and the actions of an allochthonous predator - Rapana.

The Azov-black sea basin has a rich fishing history and currently provides the surrounding regions with fresh, high-quality products. Only as a result of industrial fishing within the basin in 2019, the catch was about 81.5 thousand tons of fish and aquatic invertebrates. The largest total volume is accounted for such species as: black sea-azov herring (Alosa immaculata), tulka (Clupeonella cultriventris), Hamsa (Engraulis encrasicolus), horse mackerel (Trachurus mediterraneus), barabula (Mullus barbatus), pilengas (Liza haematocheilus), Kalkan flounder (Scophthalmus maeoticus), gobies (Neogobius), etc. Among invertebrates, mussels, black sea shrimps and Rapana are of particular importance for industrial fishing. Their total catch in 2019 was about 200 tons.

\section{Conclusions}


Thus, the fishing industry of the Krasnodar region by means of aquaculture (21.59 thousand tons) and industrial fishing makes a certain contribution to the country's food security and aims to ensure the availability of fish products in a wide range and high quality for the entire population of the region.

\section{References}

1. L. Zeng, M. Ruan, J. Liu, P. Wilde, E. N. Naumova, D. Mozaffarian, F. F. Zhang, Journal of the Academy of Nutrition and Dietetics, 119, 1085-1098 (2019) doi.org/10.1016/j.jand.2019.04.004

2. S. Kitano, N. Yamamoto, Journal of Retailing and Consumer Services, 56, 102151 (2020). doi.org/10.1016/j.jretconser.2020.102151

3. N. M. Saviolidis, B. Davíðsdóttir, L. Ilmola, A. Stepanova, M. Valman, E. Rovenskaya, Marine Policy, 117, $103967 \quad$ (2020) doi.org/10.1016/j.marpol.2020.103967

4. J. He, Ocean \& Coastal Management, 116, 150-161 doi.org/10.1016/j.ocecoaman.2015.07.017

5. R. H. Thurstan, C. M. Roberts, Marine Pollution Bulletin, 89, 5-11 (2014) doi.org/10.1016/j.marpolbul.2014.09.016

6. P. Wang, J. Ji, Y. Zhang, Aquaculture Reports, 17, 100339 (2020) doi.org/10.1016/j.aqrep.2020.100339

7. S. R. Bush, A. Pauwelussen, P. Badia, S. Kruk, D. Little, L. T. Luong, R. Newton, D. T. Nhan, M. M. Rahman, P. Sorgeloos, Y. Y. Sung, Aquaculture, 530, 735822 (2021) doi.org/10.1016/j.aquaculture.2020.735822

8. K. M. Lindland, B. Gjerstad, A. V. Krøvel, E. Ravagnan, Ocean \& Coastal Management, 179, 104827 (2019) doi.org/10.1016/j.ocecoaman.2019.104827

9. E. V. Kiyanova, M. A. Ignatenko, Main directions of aquaculture development in the Azov-black sea fisheries basin. Water bioresources and aquaculture in The South of Russia: materials of vseros. scientific and practical conference of students, postgraduates and young scientists, 46-48, Krasnodar, Kuban state University (2020)

10. G. A. Moskul, A.V. Abramchuk, N. G. Pashinova, Prospects for fisheries development of internal reservoirs of the Krasnodar territory. Water bioresources and aquaculture of the South of Russia: materials of the all-Russian scientific and practical conference dedicated to the 20th anniversary of the opening of the training course "Water bioresources and aquaculture", 180-184, Krasnodar, Kuban state University (2018).

11. A. Abramchuk, G. Moskul, N. Pashinova, N. Yurina, D. Yurin, INTERAGROMASH 2020: 13th International Scientific and Practical Conference on State and Prospects for the Development of Agribusiness, 175, 02010 (2020) doi: $10.1051 / \mathrm{e} 3 \mathrm{sconf} / 202017502010$

12. A. Abramchuk, G. Moskul, N. Pashinova, D. Shumeyko, V. Tyurin, INTERAGROMASH 2020: 13th International Scientific and Practical Conference on State and Prospects for the Development of Agribusiness, 175, 02011 (2020) doi: 10.1051/e3sconf/202017502011

13. G. A. Moskul, A. V. Abramchuk, N. G. Pashinova. Biological, ecological and morphological features of the silver carp (Hypophthalmichthys molitrix, Val., 1844) Kuban basin. Scientific research of the SCO countries: synergy and integration, 108116, Beijing (2019) 
14. G. A. Moskul, N. G. Pashinova, A. V. Abramchuk, Hypophthalmichthys nobilis (Richardson, 1846) Kuban basin (biological, ecological and morphological). Scientific research of the SCO countries: synergy and integration, 108-116, Beijing (2019)

15. P. Bronzi, M. Chebanov, J. T. Michaels, Q. Wei,, Journal of Applied Ichthyology, 35(1), 257-266 (2019) doi: 10.1111/jai.13870

16. P. Williot, G. Nonnotte, D. Vizziano-Cantonnet, M. Chebanov, The Siberian Sturgeon (Acipenser baerii, Brandt, 1869), Biology. Springer International Publishing AG, Cham, Switzerland, 1 (2018) doi.org/10.1007/978-3-319-61664-3

17. P. Williot, M. Chebanov, The Siberian Sturgeon (Acipenser baerii, Brandt, 1869) Farming. Springer International Publishing AG, Cham, Switzerland, 2 (2018) doi.org/10.1007/978-3-319-61676-6 